\title{
The influence of World Youth Day on youth ministry in Europe
}

\section{The origin of World Youth Day}

\subsection{The jubilee of young people in 1984}

Whilst ordinary jubilee years take place every 50 years, in 1983-1984, an extraordinary jubilee celebrated: the Holy Year of Redemption, proclaimed by Pope John Paul II. ${ }^{1}$ An old tradition teaches that Jesus died when he was 33 years old, so 1983 marked 1950 years after his redemptive death on the Cross. On the occasion of Palm Sunday 1984, the beginning of the Holy Week, during which the mystery of our redemption becomes apparent, Pope John Paul II invited young people to come to Rome and celebrate together. Contrary to general expectations, the young people responded generously. On Saturday 14 April 1984 some 300,000 young people from Italy and the world gathered before Rome's Cathedral - St John Lateran for the celebration of the Eucharist, followed by a pilgrimage through the streets of Rome towards St Peters' Square. Here they celebrated to-

1 Published earlier as: M. P. Remery, Národ ní a mezinárod ní di menze světových dní mládeže, "Budoucnost Církve" XXIII (2016) nr. 3-4, pp. 22-33. 
gether with the Holy Pope John Paul II. He was accompanied by another saint, Mother Teresa from Calcutta. The next day, the "Jubilee of Young People" was concluded with the Angelus, during which the Pope invited the young people to be like Mary at the feet of the Cross. He prayed that Mary would be inspirational for their faith, to construct a new world in the light of the Resurrected One. ${ }^{2}$

The Pope always tended to view young people as the future of society, since he had spent most of his time as a young priest in Poland with young people. In his days as a professor, in the weekends, he used to take his students into the mountains on hikes and kayak trips. For many hours young people spoke about all they had on their hearts, their desires and their wishes. He would, first of all, listen, and then speak to them of the love of God and how he has an answer to every question. Therefore, it is not surprising that during his papacy John Paul II called for this first large Catholic gathering for young people. This is how the Pope wanted to mark the end of the Jubilee Year of Redemption. He did this by giving to the young people the most powerful sign of our redemption: the cross. This Holy Year Cross had been near the altar St. Peter's during the entire Year of Redemption, Lent 1983 to Easter 1984. At the closing of the holy door of the Jubilee, the Holy Father said: "My dear young people, at the conclusion of the Holy Year, I entrust to you the sign of this Jubilee Year: the Cross of Christ! Carry it throughout the world as a symbol of Christ's love for humanity, and announce to everyone that only in the death and resurrection of Christ we can find salvation and redemption". ${ }^{3}$ The young people carried this large cross to the San Lorenzo youth centre in Rome, from where it started travelling throughout the world as a sign of the nearness of Jesus to young people. Since World Youth Day in Rome, in the year 2000, a copy of the Roman icon of Mary Salus Populi Romani (Protectress of the Roman People) has started travelling together with the cross, as a reminder of the invitation of the Pope to be like Mary at the feet of the Cross.

2 John Paul II, Angelus, 15 April 1984.

3 John Paul II, Remarks to young people, to whom he entrusts the cross of the Jubilee Year of Redemption, 22 April 1984. 
1985 was proclaimed by the United Nations to be the International Year of Youth. The Pope felt that it was important to repeat the experience of the year before, and again he invited young people to come and celebrate together on Palm Sunday. On Saturday 30 March 1985, young people from five continents gathered massively at the square of St John Lateran for an encounter with the Holy Father: Young people and the Pope together, as the slogan of WYD was to be in future. He told them that we are all called to be witnesses of Christ, following the apostles. This call is rooted in Baptism, and is formalized in the sacrament of Christian maturity, Confirmation. ${ }^{4}$ That evening the pope read out an apostolic letter addressed to them. After this meeting the young pilgrims could go to several churches in the city for Eucharistic adoration. The hymn Resta qui con noi (Stay with us tonight), written for the occasion, expresses the prayer that the Lord may be with us, even when the sun goes down. The next morning saw a pilgrimage towards St. Peter's Square for the concluding Mass. Over 300.000 people were present, coming, for example, from Italy, Spain and Eastern Europe, but also from other countries and continents. There were even 400 Japanese Buddhists present, and representatives of various Christian denominations.

The Holy Father's foundational letter to the youth of the world, written for that meeting, began with the words: "Dear Friends, good wishes for International Youth Year. 'Always be prepared to make a defense to any one who calls you to account for the hope that is in you' (1 Pet 3:15)". ${ }^{5}$ It was indeed a papal letter full of hope, for example when the pope exclaimed to the young readers: "In you there is hope, for you belong to the future, just as the future belongs to you. For hope is always linked to the future; it is the expectation of 'future good things."'6 The Pope linked this hope both to the divine promise of salvation given to us in Jesus, and to the expectation that young people will be using their talents - received from the same

4 John Paul II, Meeting with young people in Piazza San Giovanni Laterano, 30 March 1985.

5 John Paul II, Apostolic letter Dilecti Amici to the youth of the world on the occasion of International Youth Year, 31 March 1985, n. 1.

6 John Paul II, Apostolic letter Dilecti Amici..., op. cit., n. 1. 
24 God of salvation - in order to build good things. Thus, the person of Jesus was given the central place - as in all teaching by this Pope, as one thinks back to his initial words: "Open wide the doors to Christ."7 In his letter in 1985, the Pope considered young people to be a treasure. He did so with reference to Jesus, saying that only in him can we understand this treasure. He emphasized the personal responsibility of every human being when he said that the need to aspire for eternal life is linked to morality, which is inscribed in our conscience even before we know the commandments. After experiencing the loving gaze of Jesus upon him or her, the believer will hear the words "follow me" (Mt 19:21). These words were, for the Pope, the starting point for the sharing of his view on vocation and life. We do not come of ourselves, we come first of all from a family, and then also from a tribe, a nation, a country. Within this context, the Pope said: "little by little you recognize the 'talent' or 'talents' which each of you has". ${ }^{8} \mathrm{He}$ called on the young people to complete themselves the education received in their families and at school, looking for the truth that Jesus wants to give. Here we witness one of the key points in the teachings of John Paul II, which young people recognized as a treasure for their lives. This pope treated young people as adult Christians, inviting them to grow further: forming their consciences by a continuous self-formation. He concluded with words that he would repeat often when speaking to the youth: "You young people are the hope of the Church." And he signed the letter with these words: "I repeat [the] words of the Mother of God and I address them to you, to each one of you young people: "Do whatever Christ tells you". And I bless you in the name of the Most Holy Trinity. Amen." ${ }^{10}$

1985 became a very important year for papal teaching on youth. Take for example the theme of the 18th World Day for Peace: "Peace and youth go forward together." In his message for this day, the pope directly addressed young people, asking them to be without fear: "Do not be afraid of your own youth, and of those deep desires you have for happiness, for truth, for beauty and for lasting love!... When I look at you, the young

7 John Paul II, Homily for the Inauguration of his Pontificate, 22 Oct. 1978.

8 John Paul II, Apostolic letter Dilecti Amici..., op. cit., n. 12.

9 John Paul II, Apostolic letter Dilecti Amici..., op. cit., n. 15.

10 John Paul II, Apostolic letter Dilecti Amici..., op. cit., n. 16. 
people, I feel great gratitude and hope. The future far into the next century lies in your hands." ${ }^{11}$

Whilst showing his deep trust in the young generation, the pope called on them: "you must be people with a deep trust in man and a deep trust in the grandeur of the human vocation - a vocation to be pursued with respect for truth and for the dignity and inviolable rights of the human person."12

In December 1985, pope John Paul II told the Roman Curia that he had decided to institute a yearly day dedicated to the youth: World Youth Day. ${ }^{13}$ It was to be celebrated in dioceses around the world on Palm Sunday, with in mind the gathering on Palm Sunday 1985: "The Lord has blessed this meeting in an extraordinary way, so that, for the coming years, a World Youth Day has been instituted, to be celebrated on Palm Sunday, with the valid collaboration of the Council for Laity." ${ }^{14}$ At that occasion, the Holy Father thanked the bishops and priests around the world for all their efforts in organizing events and initiatives for young people in answer to his appeal to them in his letter to the priests on Maundy Thursday 1985. In that letter, he had written that priests working with youth first of all "need to be able to listen and know how to answer." ${ }^{15}$ Furthermore, the holy Pope said that we need not be afraid to ask a lot from young people, for they know that the true good cannot come cheap. The Pope also spoke about youth in two other letters, one addressed to the faithful of Rome, and another to the Bishops of the world. ${ }^{16}$

\subsection{World Youth Day since 1986}

The first "official" World Youth Day took place on Palm Sunday 1986 in various dioceses around the world. In Rome, it was celebrated in St John

11 John Paul II, Message for the celebration of the World Day of Peace, 1 Jan. 1985.

12 John Paul II, Message for the celebration of the World Day of Peace, op. cit.

13 John Paul II, Address to the Roman Curia offering them his Christmas greetings, 20 Dec. 1985, 3.

14 John Paul II, Address to the Roman Curia offering them his Christmas greetings, op. cit.

15 John Paul II, Letter to the priests in occasion of Maundy Thursday, 31 Mar. 1985, n. 5.

16 John Paul II, Lettera ai fedeli della diocesi di Roma, 30 March 1985; John Paul II, Lettera a tutti i vescovi della Chiesa Cattolica, 31 March 1985. 
26 Lateran, the cathedral church of Rome. "The first meeting... on Palm Sunday 1986, started a tradition of world and diocesan gatherings in alternate years, underlining, as it were, the twofold dimension, local and universal, of young people's indispensable apostolic commitment."17 The theme for the first World Youth Day recalled the first words of the pope's letter to youth in 1985: "Always be prepared to make a defence to anyone who calls you to account for the hope that is in you" (1Pt 3:15). It became the custom that - next to the yearly recurring celebration on Palm Sunday every two years there would also be an international celebration of World Youth Day, where young people would meet together with the pope.

The second World Youth Day was to be celebrated in Buenos Aires. In spite of the name of the city, the air in Argentina was not very good at the time, for the country suffered under a long dictatorship. The theme of this edition of World Youth Day was: "We ourselves have known and put our faith in God's love towards ourselves" (1Jn 4:16). Looking at the themes of the first World Youth Days, it becomes clear that each edition of the great event wants to help young people to grow in their relationship with Christ, and to share their experience with others.

A special moment was the tenth World Youth Day in Manila in 1995, which gathered the largest assembly of people in the world so far. Over 5 million people came together for the concluding Mass. Gathered around the theme "As the Father sent me, so am I sending you", the young people thought about ways in which they could bring Jesus' message of love to all the world.

Ten years later, World Youth 2005 in Köln, Germany, marked the first time that a new pope participated in the international gathering. The successor of the founding pope of WYD, Pope Benedict XVI, spoke of his experience in his home country to the Roman Curia with an enthusiasm that is almost out of character: "The World Youth Day has lived on as a great gift in the memory of those present. More than a million young people gathered... to listen together to the Word of God, to pray together, to receive the Sacraments of Reconciliation and the Eucharist, to sing and to

17 John Paul II, Letter to cardinal Eduardo Francisco Pironio on the occasion of the seminar on World Youth Days organized in Czestochowa, 8 May 1996. 
celebrate together, to rejoice in life and to worship and receive the Lord in

the Eucharist during the great meetings on Saturday evening and Sunday. Joy simply reigned throughout those days." ${ }^{18}$ And he referred to the great surprise of the German police, who were prepared for the worst: "Apart from keeping order, the police had nothing to do - the Lord had gathered his family, tangibly overcoming every frontier and barrier, and in the great communion between us, he made us experience his presence."19

The first World Youth Day of Pope Francis brought him back to his own continent. In fact, the theme of World Youth Day in Rio de Janeiro in 2013, was very similar to that of 1995 , expressing one of the core desires of the great event: to send out young missionaries to all the corners of the world. On the theme "Go and make disciples of all nations!" (cf. Mt 28:19), chosen by Pope Benedict XVI, Pope Francis said: "Today too, as always, the Lord needs you, young people, for his Church. My friends, the Lord needs you! Today too, he is calling each of you to follow him in his Church and to be missionaries. The Lord is calling you today!"20

\subsection{The importance of World Youth Day}

John Paul II explained himself why World Youth Days are so important: "The principal objective of the Days is to make the person of Jesus the centre of the faith and life of every young person so that he may be their constant point of reference and also the inspiration of every initiative and commitment for the education of the new generations. This is the slogan of every Youth Day, and through this decade, the Days have been like an uninterrupted and pressing call to build life and faith upon the rock, who is Christ."21 Thus, this foundational reference to Christ is essential for the message of John Paul II. It is essential also in the way the sons and daughters of World Youth Day experience their faith: indeed,

18 Benedict XVI, Address to the Roman Curia offering them his Christmas greetings, 22 Dec. 2005.

19 Benedict XVI, Address to the Roman Curia offering them his Christmas greetings, 22 Dec. 2005.

20 Francis, Address at the prayer vigil with young people, Saturday, 27 July 2013.

21 John Paul II, Letter to cardinal Eduardo Francisco Pironio..., op. cit. 
28 for many of them World Youth Day was the beginning or affirmation of a personal journey with Jesus Christ, who wants to be the rock on which they found their lives, and the companion with whom they live. He waits for them as they make time for prayer every day, helps them to learn more about the faith, and stimulates them to go out to tell the world of his love for every human being, serving especially the poor and needy with their own hands and possibilities.

During World Youth Day, the encounter with Christ takes mainly place through the encounter with the Church, the pope and other young people. Participants often repeat the same experience: I needed this encounter in order to make an important step forward in my faith. As John Paul II said: "The Days in fact were born, also in response to an initiative of young people themselves, of a desire to offer them a significant 'break' on the on-going pilgrimage of faith, which is indeed nurtured by meetings with young people of other nations and sharing respective experiences." 22

Pope John Paul II also spoke of the importance of World Youth Day for the ordinary youth ministry in the diocese around the world: "World Youth Day is the Church's Day for youth and with youth. This idea is not an alternative to ordinary youth ministry, often carried out with great sacrifice and self-denial. Indeed, it intends actually to consolidate this work by offering new encouragement for commitment, objectives which foster ever greater involvement and participation. By aiming to foster greater fervour in apostolate among young people, on no account the Church desires to isolate them from the rest of the community, but rather make them the protagonists of an apostolate which will spread to the other ages and situations of life in the ambit of 'new evangelisation'". ${ }^{23}$

\section{The influence of World Youth Day on youth ministry in Europe}

No-one working with youth can deny that World Youth Day (WYD) plays an important role for youth pastoral care in Europe, as also is the case

22 John Paul II, Letter to cardinal Eduardo Francisco Pironio..., op. cit.

23 John Paul II, Letter to cardinal Eduardo Francisco Pironio..., op. cit. 
in other continents. ${ }^{24}$ WYD is a well-known phenomenon as described above. ${ }^{25}$ Now, we intend to analyse several aspects of the way in which the WYD has influenced regular and everyday youth ministry in dioceses and bishops' conferences based on available literature and the author's experience in Europe. This effect is not always recognised. For example, it is surprising that a study of the youth ministry scape in Malta - thorough in almost every sense - did not mention WYD in its survey. ${ }^{26}$ Below we intend to highlight a number of ways in which WYD has influenced regular youth pastoral care.

\subsection{Street preachers}

In his encyclical Evangelii Gaudium, Pope Francis spoke about young people as street preachers, calleros de la fe in Spanish. Maybe we might render this term as "pilgrim missionaries", because "street preacher" might evoke someone standing in the market square on a vegetable crate yelling that the end is nigh and that we need to repent. Whilst not wishing to exclude possible conversions of the heart thanks to such practice, this may not always be the best approach, at least in Europe. What strikes us as more effective seems to be a preaching that is accompanied - and often preceded - by a Christian way of life able to make a difference in the world. Probably, this is precisely how we should interpret the words of Pope Francis, when he says: "How beautiful it is to see that young people are street preachers (callejeros de la fe), joyfully bringing Jesus to every street, every town square and every corner of the earth!"27 This is not a utopian vision, it is something those working with young people have all witnessed. Young people returning from World Youth Day, trying to live as good Christians displaying care for the people around them, speak-

24 Published earlier as: I giovani "viandanti della fede". L'influsso delle GMG sulla pastorale giovanile in Europa, in: Una Chiesa giovane testimone della gioia del Vangelo. IV Convegno europeo di pastorale giovanile, Città del Vaticano 2016, pp. 103-115.

25 Cfr. e.g. P. Zuchniewicz, Szukałem Was. Jan Paweł II i Światowe dni Młodzieży, Radom 2005; M. Muolo, Generazione GMG. La storia della Giornata Mondiale della Gioventù, Milano 2011; J. Balik, Giovanni Paolo II in dialogo con i giovani, Roma 2013.

26 Cfr. Diocesan Commission KDZ, Grassroots. The youth ministry scape in Malta, "Census Youth and Adolescences" 2013, pp. 46-49.

27 Francis, Encyclical Letter Evangelii Gaudium, 24 Nov. 2013, n. 106. 
30 ing with enthusiasm of their WYD experience including their encounter with Christ, are very strong and convincing evangelizers. They preach the Gospel wherever they go like pilgrim missionaries, without any official "soap box" or pulpit to stand on, simply witnessing their enthusiasm for the Lord and His Church. In this way, WYD has contributed a lot to the New Evangelization called for by all recent Popes. As Pope Francis says to those responsible for youth ministry in Europe: "While you sow the Word of the Lord in this vast field that is European youth, you have the opportunity for bearing witness to the reasons for the hope that is within you, with gentleness and respect. You are able to help the young to realise that faith is not opposed to reason, and thus to accompany them as they become joyful agents for the evangelization of their peers." ${ }^{28}$

For those working with youth today it may be difficult to imagine youth pastoral care without WYD. Still, there was a time only 30 years ago, when the first WYD had still to be announced. Of course, there were all kinds of initiatives for young people, all around the globe. Just to mention one more or less random example, we can look to Saint John Paul II, who as a young priest used to take groups of young people into the mountains for canoeing trips, during which they would have endless discussions about topics of faith. If there is one image that is emblematic for Catholic youth pastoral care, it is that of a canoe turned over, placed on top of some stones, and changed into an altar: here everything discussed and experienced can be offered to the Lord Himself. Every youth pastor will be able to come up with other images, maybe in line with the long dialogue sessions I myself used to have with young people at the church door after Mass, which eventually led to the international project Tweeting with GOD which attempts to do precisely that: join dialogues about faith with that which is most important and central: our relationship with the Lord. ${ }^{29}$ In this context Pope Francis says: "Youth pastoral ministry must engage with the questions posed by the youth of today, and from this starting point, initiate a real and honest dialogue to bring Christ into their lives. And a true

28 Francis, Letter to the participants of the IV European Conference on Youth Ministry, 11 Dec. 2014.

29 Cfr. M. Remery, Tweeting with GOD. Big Bang, prayer, Bible, sex, Crusades, sin, career, San Francisco 2015; www.tweetingwithgod.com (28.11.2018) 
dialogue in this sense can be achieved by those who experience a person-

al relationship with the Lord Jesus, which then overflows into their relationships with their brethren." 30

\subsection{Cohesion}

We must conclude that there were many initiatives pertaining to youth pastoral care even before the institution of World Youth Day. So, what has changed in youth pastoral care with the introduction of WYD? Before WYD there were indeed small and large groups of youth pastoral care, though often without the cohesion we observe today. In many places WYD has helped to bring these groups together, and in some countries, it was as a result of WYD that a proper national youth office was set up. For example, in the Principality of Monaco diocesan youth ministry started in 2000 with WYD. Now the mission of youth ministry is being expanded with those in charge of education and vocation ministry. In Poland there is no national office for youth pastoral care. There is however a WYD office which also has been tasked to coordinate the pastoral care of young people on a national level.

Obviously, with regard to national structures for youth ministry there are great differences between the countries of Europe. Some, such as Portugal, have placed much emphasis on this theme for a long time. Where many countries have separate departments dealing with youth, university pastoral care, vocations, etc., France has joined all these areas of operation into one great council for the pastoral care of children and youth. On the contrary, England and Spain do not have a large national structure, as it is a tradition to do as much as possible at individual diocese level. Germany and Italy on the contrary are examples of countries where the national structure is given much more importance. It should be clear that in a number of countries in the East of Europe it was only after the great changes of the 1990s that national structures were set up. In Croatia this was the case in 2002, and an obvious influence of WYD can be observed

30 Francis, Letter to the participants of the IV European Conference on Youth Ministry, 11 Dec. 2014. 
32 in the biannual national youth day that gathers over 30.000 young peo- $\quad$ ple from all around the country. Depending on time and place, national and international circumstances have led to different set-ups. Still, some general tendencies can be observed.

The great strength of WYD is that it has given enthusiasm to sometimes large groups of youth from the same country, and a new awareness of the importance of a New Evangelization. Seeing tens of thousands (and more!) young people like themselves is extremely important for each of the participants, especially when they come from a largely secularized country, or from a country where for various reasons they would not see large groups of faithful together, let alone young faithful. The same goes for their pastors, who also return from WYD with a new enthusiasm.

With good reason an important slogan of WYD is "Young people and the Pope together". Not only does WYD lead to more cohesion between the members of local Churches, but it also helps to see their group in the perspective of the universal Church as led by the Pope. So many young people have been touched profoundly by this experience, as a result of which their lives change drastically. ${ }^{31}$ WYD has helped many young people to discover that the Pope is part of our Church, and thus of our life as Christians, leading our Church community as one flock towards Jesus. Thus, this two or three-yearly international youth meeting has led to cohesion between local youngsters, to cohesion between youth groups in the local Church, but also to cohesion between individuals and groups on the one hand with the Universal Church on the other.

\subsection{Diversity}

Before World Youth Day, local youth ministry often reflected mainly the own reality of a given group. It was difficult to have an image of how things could be different, as only few young individuals and few pastors had had the opportunity to meet and experience other dimensions of our Catholic Church. Of course, it is correct to say that the means of commu-

31 Cfr. e.g. P. Zuchniewicz, Miracles of John Paul II, Toronto 2006, pp. 144-171; F. Vayne, A. Rollier, Jean-Paul II, les jeunes et les JMJ, Les Plans sur Bex 2005, pp. 138-139. 
nication were not as fast and globalized as today, and it is worth bearing in mind that other factors may also play a role.

This brings us to another important element of WYD, namely the discovery of the diversity of the Church. Unified as we are under and with one leader the Pope, there are, at the same time, many colours and ways of being Catholic. WYD has helped many youngsters to open their eyes to the very different realities of which our Church consists. This helps us to realize that our own way of doing things may not be the best way, and definitely is not the only way to be a Catholic.

Observing diversity often is a wonderful starting point for a conversation about faith and about the history and present of our Church. For example, I myself have spoken to young people who had their first opportunity to see the beautiful - to them tiara-like - mitre worn by Bishops of the Oriental Rites, which led to their discovery of a completely new reality within our one Catholic Church. I am also thinking of Maria, a young person who came to ask me once during WYD what I thought about the female protestant pastor, complete with roman collar and miniskirt, who was parading in front of our lodging with her arm around her husband, also a protestant pastor, and also wearing a roman collar. Some of the themes we discussed subsequently with her group at and after WYD included Protestantism, purgatory, married priests, the validity of the Sacraments, chastity and the best way of living one's sexuality. In another situation, the group might have been too shy or uninspired to ask these questions, which were provoked by observing the diversity between Christians.

\subsection{Enthusiasm}

We all know examples of people that underwent a permanent change during World Youth Day. With their enthusiasm they subsequently became youth leaders in our local Churches. ${ }^{32}$ It is precisely this enthusiasm that has encouraged groups of young people, together with their pastors,

32 Cfr. F. Vayne, A. Rollier, Jean-Paul II, les jeunes et les JMJ, Les Plans sur Bex 2005, op. cit., pp. 108-111. 
34 to structure or re-structure youth pastoral care. Enthusiasm is a very important fruit of World Youth Day, and it will be mentioned several times in this article. This enthusiasm is such that even a controversial secular writer like Michel Houellebecq, who went to WYD in Paris "out of curiosity", was impressed by the faces of young people who attended the event. ${ }^{33}$

There is also a more general kind of enthusiasm that is brought back home from WYD. This can be experienced in many dioceses and parishes, often already during the time leading up to WYD, and which continues to mark its follow-up. This enthusiasm, both general and individual, is one of the most important ways in which WYD influences life in the local Church. In fact, asked about the impact of WYD on youth ministry in their respective countries, many national delegations operating in this field mentioned enthusiasm as one of the main factors that inspired change.

\subsection{Prayer}

For a number of young people World Youth Day is the first encounter with prayer and the sacraments, notably the Sacrament of Reconciliation and the Eucharist. Others have been able to deepen their relation with the Lord in prayer or have discovered new ways to pray. WYD demonstrates that prayer and enjoyment can go together. Just think of the prayer vigil, which beautifully combines festivities with prayer, and instruction with contemplation. Often this vigil is the moment when the words of the Pope reach deepest in the hearts of the participants, who have all night to contemplate them as they continue to party. As Becquart noted, young Catholics have a great inner thirst for liturgy and prayer. ${ }^{34}$

Some of the participants are rather experienced when it comes to prayer, others do not know much about it... yet. However, for each of the participants there is something to be found. Moreover, this experience of prayer often gives young people a taste for prayer, one they bring home and which leads them to start prayer groups and search for other ways to

33 Cfr. M. Chaudey, J.-P. Denis, Michel Houellebeca : 'Je ne suis plus athée', "La Vie" 29 Jan. 2015.

34 Cfr. N. Becquaert, Evangeliser les jeunes adultes dans le souffle des JMJ, Paris 2013, p. 21 [Documents Épiscopat, N. 12/2013]. 
continue their encounter with Jesus Christ. I am thinking of Flavia, who

during the prayer vigil in Madrid came to me at the entrance of the adoration tent, where she had just experienced deep within herself that Jesus was calling her to put everything aside to serve him. She wanted to go and see her boyfriend, to whom she had been engaged, and tell him right there and then that she would no longer marry him. During our conversation we discovered that in fact that decision would be a bit too hasty. This experience during WYD was the start of a long path of personal prayer and pastoral accompaniment in daily life. "This pastoral ministry", said Pope Francis, "consists of walking with them, accompanying them personally in the complex and at times difficult contexts in which they are immersed." 35 Today Flavia is very happily married. And that brings us to yet a further point.

\subsection{Vocations}

Among those working in youth ministry today, there are many "Sons and daughters of World Youth Day". They were young people who found their vocation partly or fully during WYD. ${ }^{36}$ From the beginning, WYD has had a great influence on the ability of young people to choose their vocation. The reason for this is found in all the elements mentioned above: Cohesion in the sense of belonging to a Church where each has his or her own contribution to bring; Diversity in the sense that one does not have to do what others do and instead everyone has a personal vocation; Enthusiasm in the sense of seeing that it is possible to choose enthusiastically what is really important to us; Prayer because it is the person of Jesus Christ who is calling, and no-one else. In fact, this global view of vocation is precisely what Citrini refers to, in the Italian dictionary on the pastoral care of vocations, when he says: "taking 'vocation' in the most open dynamic sense, every pastoral moment is vocational, as far as it concerns the response of a person to the voice of God and the condi-

35 Francis, Letter to the participants of the IV European Conference on Youth Ministry, 11 Dec. 2014.

36 Cfr. P. Zuchniewicz, Narodzini Pokolenia JP2, Warszawa 2007, esp. pp. 104-153. 
36 tions of this response: this is how it always was". ${ }^{37}$ Hence Pope Francis says: "Youth pastoral ministry is required to offer to the young a path of vocational discernment, to prepare them to follow Jesus on the way of conjugal and family life, or that of special consecration in the service of God's Kingdom". ${ }^{38}$

\subsection{Event}

One of the complaints you may hear against World Youth Day is that it might become too much of a singular event, not rooted in the daily life of the young faithful and the Church. This criticism is partly understandable. In the case of those who consider WYD not related to the regular pastoral care of youth, this criticism is even justified. But that is precisely the point: if prepared for and lived out correctly, WYD cannot but have a great influence on youth pastoral care. It is my own experience, shared by many, that for those who participate wholeheartedly in WYD it is impossible to return unchanged. I have lived quite a few edition sand brought home something different from each of them.

In the first place, there is the immediate preparation of WYD. If taken seriously, the group meets at least a few times beforehand to discuss practical details, but also to pray and to prepare spiritually. And after the WYD event there is the continuation of pastoral care. This follow-up is of great importance for the success of WYD. In this way, the one-time experience of WYD becomes part of the larger system of pastoral care for youth, in groups, parishes, dioceses and Church provinces.

Another important element of World Youth Day is the effect it has on the host country. Superficial observers mainly speak only about a possible financial deficit of the local WYD Church. There is however much more to say about the effect of WYD on hosting Churches - an impact which cannot be expressed in financial figures - although a Catholic popula-

37 T. Citrini, Vocazione (Teologia della), in: Dizionario di Pastorale Vocazionale, Roma 2002, p. 1290.

38 Francis, Letter to the participants of the IV European Conference on Youth Ministry, 11 Dec. 2014. 
tion with new élan will surely render Sunday collections more fruitful!

But the main change is in the attitude of the faithful. From the beginning, thousands of younger and older volunteers belonging to the local Church work together for the success of the event. It is beyond the scope of this article to study this effect in detail, but as mentioned above, the event can have a lasting effect precisely because people are being changed by it.

\subsection{Conclusion}

In conclusion, let us observe once more the elements evoked above, to try to see some relation between these and their influence on the organization of youth pastoral care in our countries. Becquaert asked young French people who signed up for World Youth Day in Madrid why they wanted to go. The three most quoted answers were: "To live out a strong spiritual experience", "To meet young people from all around the world", and "To give to the world a dynamic view of the Church." ${ }^{39}$ Although in other countries the answers might be different, the quotes contain much from what has been discovered in this article.

The cohesion experienced within one's own group, the local Church and with the universal Church has an important influence on the daily pastoral care of young people, initiated by participants themselves and the pastors that accompany them during WYD. Also, the diversity experienced during the WYD pilgrimage leads to a broader view of what Church is about and how Church should be. In more secular countries it has helped to establish a stronger position against certain circulating criticisms of faith and Church, whilst in more traditionally Catholic countries it has helped to see that also in a more secularized environment faith is possible. Whichever way it is looked at, the message is that you are not alone! We are many and diverse, both locally and universal. Such is the Catholic Church.

The enthusiasm brought home from WYD has given a great impulse to existing youth pastoral care and has stimulated the development of very

39 N. Becquaert, Evangeliser les jeunes adultes dans le souffle des JMJ, Paris 2013, 22 [Documents Épiscopat, N. 12/2013]. 
different new initiatives. In this sense one can truly speak of a renewal of youth pastoral care brought about by the participation of groups of young people at WYD. In many cases, the encounter with prayer during WYD, has led to a desire to learn more and to work on a personal relationship in prayer with Jesus Christ. On the basis of the WYD experience, together with the experience of prayer, many young people have been able to take that final step, or to initiate or continue a path towards embracing their personal vocation in life. In his encyclical Evangelii Gaudium, Pope Francis describes the importance of everyday pastoral care, so that "despite the present crisis of commitment and communal relationships, many young people are making common cause before the problems of our world and are taking up various forms of activism and volunteer work. Some take part in the life of the Church as members of service groups and various missionary initiatives in their own dioceses and in other places." (EG 106) That is indeed the desired result of WYD, which is therefore much more than an event: those who live the days of WYD with openness and surrender will not return unchanged to their daily lives. Young pilgrim missionaries back from WYD are the best evangelizers of their peers. ${ }^{40}$ They are like Jesus' disciples ${ }^{41}$ : their meeting with the Lord, perhaps during WYD, has a lasting effect on their daily lives and those of others.

\section{Chronicle of World Youth Day 1986-2016 ${ }^{42}$}

1984 Rome. St Peter's Square, Palm Sunday (15 April 1984). International youth meeting on the occasion of the Holy Year of the Redemption. The Pope presents and entrusts young people with the Cross (22 April 1984).

1985 Rome. St Peter's Square - Palm Sunday (31 March 1985). International youth meeting on the occasion of International Youth Year of

40 N. Becquaert, L'évangelisation des jeunes, un déf. Église@jeunes2.0, Entretiens avec Yves de Gentil-Baichis, Paris 2013, pp. 72-73.

41 Cfr. Luke 24:28-34; John 1:35-41.

42 Cfr. http://www.vatican.va/gmg/documents/gmg_chronicle-wyd_20020325_en.html (29.11.2018). 
the UN. The Holy Father addresses an Apostolic Letter to the youth of

the world (31 March 1985). He announces the institution of World Youth Day (20 December 1985).

1986 1st World Youth Day. Theme: "Always be prepared to make a defence to anyone who calls you to account for the hope that is in you" (1Pt 3:15). Celebration (diocesan level) - Palm Sunday (23 March 1986).

1987 2nd World Youth Day. Theme: "We ourselves have known and put our faith in God's love towards ourselves" (1Jn 4:16). Celebration (international level) - Buenos Aires, Argentina (11-12 April 1987).

1988 3rd World Youth Day. Theme: "Do whatever he tells you" (Jn 2:5). Celebration (diocesan level) - Palm Sunday (27 March 1988).

1989 4th World Youth Day. Theme: "I am the Way, the Truth and the Life" (Jn 14:6). Celebration (international level) - Santiago de Compostela, Spain (15-20 August 1989).

1990 5th World Youth Day. Theme: "I am the vine, you are the branches" (Jn 15:5). Celebration (diocesan level) - Palm Sunday (8 April 1990).

1991 6th World Youth Day. Theme: "You have received a spirit of sonship" (Rom 8:15).

Celebration (international level) - Czestochowa, Poland (10-15 August 1991).

1992 7th World Youth Day. Theme: "Go into all the world and preach the Gospel” (Mk 16:15). Celebration (diocesan level) - Palm Sunday (12 April 1992).

1993 8th World Youth Day. Theme: "I came that they might have life, and have it to the full" (Jn 10:10). Celebration (international level) Denver, USA (10-15 August 1993).

1994 9th World Youth Day. Theme: "As the Father sent me, so am I sending you" (Jn 20:21). Celebration (diocesan level) - Palm Sunday (27 March 1994)

1995 10th World Youth Day. Theme: "As the Father sent me, so am I sending you” (Jn 20:21). Celebration (international level) - Manila, Philippines (10-15 January 1995).

1996 11th World Youth Day. Theme: "Lord, to whom shall we go? You have the words of eternal life" (Jn 6:68). Celebration (diocesan level) Palm Sunday (31 March 1996). 
1997 12th World Youth Day. Theme: “Teacher, where are you staying? Come and see" (cf. Jn 1:38-39). Celebration (international level) - Paris, France (19-24 August 1997).

1998 13th World Youth Day. Theme: "The Holy Spirit will teach you all things" (cf Jn 14:26). Celebration (diocesan level) - Palm Sunday (5 April 1998).

1999 14th World Youth Day. Theme: "The Father loves you" (cf. Jn 16:27). Celebration (diocesan level) - Palm Sunday (28 March 1999).

2000 15th World Youth Day - Youth Jubilee. Theme: "The Word became flesh and dwelt among us" (In 1:14). Celebration (international level) Rome, Italy (15-20 August 2000).

2001 16th World Youth Day. Theme: "If any want to become my followers, let them deny themselves and take up their cross daily and follow me" (Lk 9:23). Celebration (diocesan level) - Palm Sunday (8 April 2001).

2002 17th World Youth Day. Theme: "You are the salt of the earth... you are the light of the world" (Mt 5: 13,14). Celebration (international level) - Toronto, Canada (23-28 July 2002).

2003 18th World Youth Day. Theme: “Behold, your mother!” (Jn 19,27). Celebration (diocesan level) - Palm Sunday (13 April 2003).

2004 19th World Youth Day. Theme: "We wish to see Jesus" (Jn 12,21). Celebration (diocesan level) - Palm Sunday (4 April 2004).

2005 20th World Youth Day. Theme: "We have come to worship Him" (Mt 2,2). International celebration - Cologne, Germany (August 16-21).

2006 21st World Youth Day. Theme: "Your word is a lamp to my feet and a light to my path" (Ps 119, 105). Celebration (diocesan level) - Palm Sunday (9 April 2006).

2007 22nd World Youth Day. Theme: "Just as I have loved you, you also should love one another" (Jn 13,34). Celebration (diocesan level) Palm Sunday (8 April 2007).

2008 23rd World Youth Day. Theme: "You will receive power when the Holy Spirit has come upon you; and you will be my witnesses" (Acts 1, 8). International celebration - Sydney, Australia (15-20 July 2008).

2009 24th World Youth Day. Theme: "We have set our hope on the living God" (1 Tm 4:10). Celebration (diocesan level) - Palm Sunday (5 April 2009). 
2010 25th World Youth Day. Theme: "Good Teacher, what must I do

to inherit eternal life?” (Mk 10:17). Celebration (diocesan level) - Palm Sunday (28 March 2010).

2011 26th World Youth Day. Theme: "Planted and built up in Jesus Christ, firm in the faith" (cf Col 2:7). International celebration - Madrid, Spain (16-21 August 2011).

2012 27th World Youth Day. Theme: "Rejoice in the Lord always!" (cf. Phil 4:4). Celebration (diocesan level) - Palm Sunday (1 $1^{\circ}$ April 2012).

2013 28th World Youth Day. Theme: "Go and make disciples of all nations!" (cf. Mt 28:19). International celebration - Rio de Janeiro, Brazil (22-29 July 2013).

2014 29th World Youth Day. Theme: "Blessed are the poor in spirit, for theirs is the kingdom of heaven" (Mt 5:3). Celebration (diocesan level).

2015 30th World Youth Day. Theme: "Blessed are the pure in heart, for they shall see God" (Mt 5:8). Celebration (diocesan level).

2016 31st World Youth Day. Theme: "Blessed are the merciful, for they shall obtain mercy" (Mt 5:7). International celebration - Krakow, Poland.

\section{Bibliography}

\section{Pontifical sources}

Benedict XVI, Address to the Roman Curia offering them his Christmas greetings, 22 December 2005.

Francis, Address at the prayer vigil with young people, Saturday, 27 July 2013.

Francis p.p., Encyclical Letter Evangelii Gaudium, 24 November 2013

Francis p.p., Letter to the participants of the IV European Conference on Youth Ministry,

11 December 2014

John Paul II, Angelus, 15 April 1984.

John Paul II, Remarks to young people, to whom he entrusts the cross of the jubilee year of redemption, 22 April 1984.

John Paul II, Meeting with young people in Piazza San Giovanni in Laterano, 30 March 1985.

John Paul II, Apostolic letter Dilecti Amici to the youth of the world on the occasion of International Youth Year, 31 March 1985.

John Paul II, Homily for the Inauguration of his Pontificate, 22 October 1978.

John Paul II, Message for the celebration of the World Day of Peace, 1 January 1985. 
John Paul II, Address to the Roman Curia offering them his Christmas greetings, 20 December 1985.

John Paul II, Letter to the priests in occasion of Maundy Thursday, 31 March 1985.

John Paul II, Lettera ai fedeli della diocesi di Roma, 30 March 1985.

John Paul II, Lettera a tutti i vescovi della Chiesa Cattolica, 31 March 1985.

John Paul II, Letter to cardinal Eduardo Francisco Pironio on the occasion of the seminar on World Youth Days organized in Czestochowa, 8 May 1996.

\section{Other sources}

Diocesan Commission KDZ, Grassroots. The youth ministry scape in Malta, "Census Youth and Adolescents" 2013, pp. 46-49.

Balik J., Giovanni Paolo II in dialogo con i giovani, Roma 2013.

Becquaert N., Evangeliser les jeunes adultes dans le souffle des JMJ, "Documents Épiscopat" N. 12/2013 p. 21.

Becquaert N., L'évangelisation des jeunes, un défi. Église@jeunes2.0, Entretiens avec Yves de Gentil-Baichis, Paris 2013.

Citrini T., "Vocazione (Teologia della)", in: Dizionario di Pastorale Vocazionale, Roma 2002., p. 1290.

Chaudey M., Denis J.-P., Michel Houellebecq : 'Je ne suis plus athée', "La Vie” 29 Jan. 2015.

Muolo M., Generazione GMG. La storia della Giornata Mondiale della Gioventù, Milano 2011.

Remery M., Tweeting with GOD. Big Bang, prayer, Bible, sex, Crusades, sin, career, San Francisco 2015, www.tweetingwithgod.com (28.11.2018).

Remery M. P., Národ ní a mezinárod ní di menze světových dní mládeže, "Budoucnost Církve" XXIII (2016) nr. 3-4.

Una Chiesa giovane testimone della gioia del Vangelo. IV Convegno europeo di pastorale giovanile, Città del Vaticano 2016.

Vayne F., Rollier A., Jean-Paul II, les jeunes et les JMJ, Les Plans sur Bex 2005.

Zuchniewicz P., Szukałem Was. Jan Paweł II i Światowe dni Młodzieży, Radom 2005

Zuchniewicz P., Miracles of John Paul II, Toronto 2006.

Zuchniewicz P., Narodziny Pokolenia JP2, Warszawa 2007. 